\title{
Assessment of Surface Water Quality in an Arsenic Contaminated Village
}

\author{
Kumud C. Saikia and Susmita Gupta \\ Department of Ecology and Environmental Science, \\ School of Environmental Sciences, Assam University, Silchar, 788011, India
}

Received 2011-07-16, Revised 2012-08-27; Accepted 2012-08-31

\begin{abstract}
Arsenic contamination of ground water has occurred in various parts of the world, becoming a menace in the Ganga-Meghna-Brahmaputra basin (West Bengal and Assam in India and Bangladesh). Recently arsenic has been detected in Cachar and Karimganj districts of barak valley, Assam, bordering Bangladesh. In this area coli form contamination comprises the major constraint towards utilization of its otherwise ample surface water resources. The local water management exploited ground water sources using a centralized piped water delivery scheme without taking into account the geologically arsenic-prone nature of the sediments and aquifers in this area. Thus surface water was the suggestive alternative for drinking water in this area. The present study investigated surface water quality and availability in a village of Karimganj district, Assam, India contaminated with arsenic for identifying the potential problems of surface water quality maintenance so that with effective management safe drinking water could be provided. The study revealed that the area was rich in freshwater ecosystems which had all physico-chemical variables such as water temperature, $\mathrm{pH}, \mathrm{DO}$, total alkalinity, free $\mathrm{CO}_{2}$, heavy metals like lead, chromium and cadmium within WHO standards. In contrast, coli form bacteria count was found far beyond permissible limit in all the sources. Around $60 \%$ people of the village preferred ground water for drinking and only $6 \%$ were aware of arsenic related problems. The problem of bacterial contamination could be controlled by implementing some ameliorative measures so that people can safely use surface water. Inhabitants of the two districts should be given proper education regarding arsenic contamination and associated health risk. Effluents should be treated to acceptable levels and standards before discharging them into natural streams.
\end{abstract}

Keywords: Arsenic Contamination, Surface Water, Ground Water, World Health Organization, Water Temperature (WT), Carbon Dioxide, Total Alkalinity (TA), Dissolved Oxygen (DO), Electrical Conductivity (EC)

\section{INTRODUCTION}

The World Health Organization (WHO, 2002) estimates 1.7 million deaths and 54.2 million Disability Adjusted Life Years (DALYs) lost worldwide per year due to unsafe water, hygiene and sanitation. In India more than a million child deaths per year results from waterborne diseases like diarrhea (Parikh et al., 1999). According to NWP (2002), drinking water needs of human beings and animals should be the first priority on any available water. The availability of safe and reliable sources of water is an essential pre-requisite for the establishment of a stable community. The hydrobiological cycle stores about $0.6 \%$ of water as ground water and accounts for $25 \%$ of our fresh water (Mahapatra and Mishra, 2005). Due to several anthropogenic activities ground water is found to be contaminated with heavy metals like arsenic, fluoride.

In the north eastern part of India, surface water from ponds and rivers comprised the traditional water supply source. In recent years, these systems were contaminated by high densities of pathogenic microorganisms which caused various waterborne diseases, such as diarrhoea, gastroenteritis, typhoid and cholera. This was mostly accompanied by high turbidity that rendered the aesthetical quality of this water poor. For avoiding these problems the water providers decided to exploit ground water sources in the centralized piped

Corresponding Author: Susmita Gupta, Department of Ecology and Environmental Science, School of Environmental Sciences, Assam University, Silchar, 788011, India Tel: +91-03842-267341 Fax: + 91- 03842-270802 
water supply schemes without taking into account the geologically arsenic-prone nature of the sediments and aquifers in this area. Ground water became very popular because of its convenience and crystal clear nature However, within less than a decade arsenic was detected in number of wells of NE India.

Arsenic contamination in ground water is a major problem in more than 20 countries all over the world which includes Asian countries (Thailand, Taiwan, mainland China, Vietnam and the Ganges Delta of Bangladesh and West Bengal, India). In North East India, arsenic has been detected in 21 districts of Assam, three districts of Tripura, six of Arunachal Pradesh, four of Manipur and two of Nagaland (Singh, 2004). Prolonged exposure to water contaminated with arsenic is highly toxic to humans causing skin and bladder cancer, melanosis and keratosis. Ground water contamination with heavy metals like As, F. is generally irreversible. Watermanagement decisions are very much important as they have environmental, physical,social and economic impacts. It is, therefore, necessary to have the most relevant information for arriving at rational decisions that will result in the maximum amount of benefit to most people (Gupta and Deshpande, 2004). The key role of a Government should be to maintain and ensure an adequate supply of chemically and microbiologically safe drinking water which is acceptable to the people. This makes chemical and microbiological monitoring of surface and ground water sources mandatory. According to Smith et al. (2000) the fundamental intervention is the immediate identification and provision of arsenic-free drinking water.

The Karimganj district $\left(92^{\circ} \mathrm{C} 15^{\prime}-92^{\circ} \mathrm{C} 35^{\prime}\right.$ east and $24^{\circ} \mathrm{C} 15^{\prime}-25^{\circ} \mathrm{C} 55^{\prime}$ north.) is one of the 21 arsenic affected district of Assam where arsenic concentration exceeded the permissible limit $50 \mu \mathrm{gL}^{-1}$. It is bounded on the North and west by Bangladesh (Fig. 1). Hence it was thought that a preliminary study on some dimensions of surface and ground water quality of Bidyanagar village of Karimganj district would be of value for developing management strategies for maintaining potable water quality.

\section{MATERIALS AND METHODS}

Three replicate water samples were collected from the sub-surface layer in PVC and BOD bottles (for estimating dissolved oxygen) from ten sites of different water sources (four ponds, four handpumps and two sites of River Longai) of Bidyanagar Village. Water Temperature (WT), $\mathrm{pH}$ and Electrical Conductivity (EC) were measured by mercury bulb thermometer, $\mathrm{pH}$ meter and Conductivity-TDS Meter, respectively.

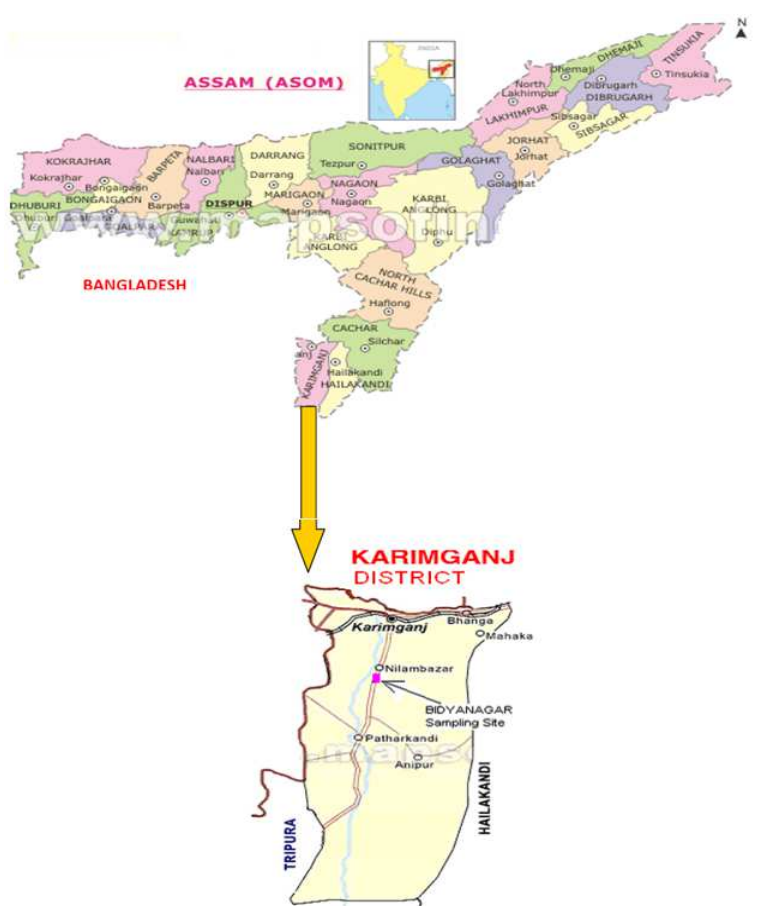

Fig. 1. Map showing the location of the Bidyanagar village of Karimganj district, Assam

Dissolved Oxygen (DO), Total Alkalinity (TA) and free Carbon Dioxide $\left(\mathrm{CO}_{2}\right)$ were analyzed by standard methods (Eaton and Franson, 2005). Cadmium (Cd), Chromium $(\mathrm{Cr})$ and Lead $(\mathrm{Pb})$ of water samples were estimated in a Perkin-Elmer 2380 flame atomic absorption spectrophotometer.

For microbiological analysis three replicate water samples were collected in sterilized bottles from all the sites. E.coli and other coli form analysis was done using membrane-filter technique with MS-Endo broth (Eaton and Franson, 2005) and expressed as MPN100 $\mathrm{ml}^{-1}$. For collecting various information regarding socioeconomic condition, surface and ground water usage, related health risk. a structured and semi-structured questionnaire containing both open and close-ended questions was used (Murdock et al., 1986).

\section{RESULTS}

Physico-chemical and biological properties of water samples of different sites are shown in Table 1.

The WT of the surface water sources ranged from $29.5-32.33^{\circ} \mathrm{C}$. The range of DO $\left(5.8-8.81 \mathrm{mg} \mathrm{L}^{-1}\right)$, free CO2 (1.1-4.77 $\left.\mathrm{mg} \mathrm{L}^{-1}\right)$, EC (98.13-216.77) and TA (45$90 \mathrm{mg} \mathrm{L}^{-1}$ ) was within the permissible limit of WHO (2004). The $\mathrm{pH}$ ranged from 5.98-8.12. 

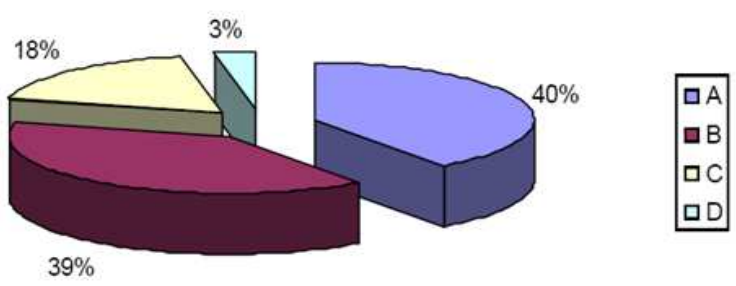

Fig. 2. Educational status of the people of Bidyanagar village. A-Below 10th standard, B- Above 10th standard, CAbove 12th standard, D- Graduate
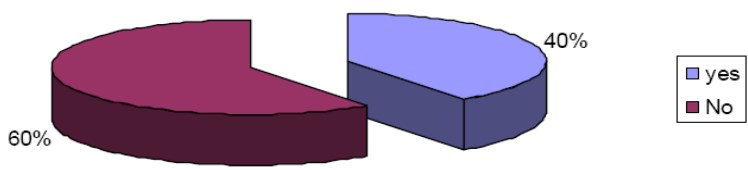

Fig. 3. Awareness level of Arsenic contamination of water in Bidyanagar village

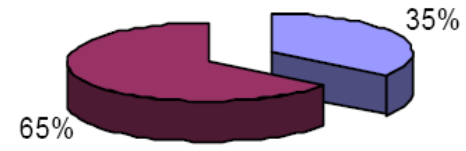

$\square$ Ground water

$\square$ Surface water

Fig. 4. Preference for drinking water source by the people of Bidyanagar
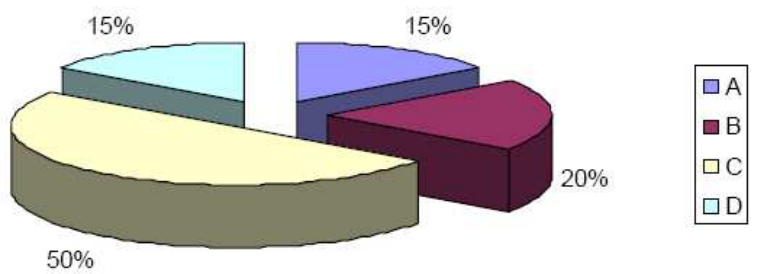

Fig. 5. Employment status of the people of Bidyanagar village. A-Govt. job, B- Private Job, C-Cultivator, DUnemployed
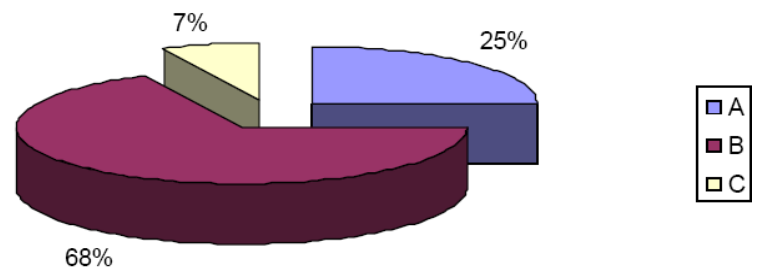

Fig. 6. Monthly expenditure of the people of Bidyanagar village. A- Rs. 3000 and more, B- Rs. 5000 and more, C- Rs.6000 and more

The concentration of $\mathrm{Cr}, \mathrm{Cd}$ and $\mathrm{Pb}$ in all the drinking water sources ranged from 8.6-22.3, 1.7-4.3, 6.6-22.6 $\mu \mathrm{gL}^{-1}$, respectively. The number of E.coli in different drinking water sources varied from 3.3-50 MPN $100 \mathrm{ml}^{-1}$. The number of other fecal coliform ranged from 573.3-8856.7 MPN100 $\mathrm{mL}^{-1}$ Table 1. While $60 \%$ of households were aware of arsenic contaminated water, the remaining $40 \%$ of families 101 were limitedly informed. In the village $40 \%$ people were below 10th standard, $39 \%$ above, $18 \%$ passed 12 th standard and $3 \%$ were graduate. $35 \%$ people of the village preferred ground water for drinking, $65 \%$ people preferred surface water. $15 \%$ of the total population was employed by the government, $20 \%$ in private sector and $50 \%$ was engaged in cultivation. The remaining $15 \%$ were unemployed. Only 7\% household of the village belonged to the expenditure category of Rs.> 6000 . $68 \%$ household belonged to the category of Rs. $>5000$ and 25\% belonged to Rs.> 3000 (Fig. 2-6).

\section{DISCUSSION}

The importance of adequate water quantity for human health has been recognized for many years and there has been an extensive debate about the relative importance of water quantity, water quality, sanitation and hygiene in protecting and improving health (Esrey et al., 1985). Study revealed that in the Bidyanagar village surface water availability is not a problem; however, water quality is. The highest temperature in river water might be due to the fact that river receives effluent from various sources which increases the temperature. The range of DO conformed to the previous studies on the ponds of Cachar district of Assam (Gupta, 2004; Bhuiyan and Gupta, 2007; Gupta et al., 2008). However, record of very low concentration of free $\mathrm{CO} 2$ did not agree with the previous studies. A study on the water quality of Tamparaparani river of Tamil Nadu (Martin et al., 2000) revealed similar low concentration of free $\mathrm{CO} 2$. Except pond 2, $\mathrm{pH}$ of all the sites were also well within the permissible range of WHO (2004). The acidic nature of water of Pond 2 could be due to the contamination by sewage and domestic wastes in the water sources (Dwivedi and Pandey, 2002).

The problem of environmental pollution due to toxic metals has begun to cause concern on account of geoaccumulation, bioaccumulation and biomagnifications (Naik and Wanganeo, 2008). Iron among other trace elements is known to play a significant role in human health for example, a deficiency of $\mathrm{Fe}$ causes anemia. On the other hand, an excess of $\mathrm{Fe}$ may cause gastrointestinal irritation. In the present study, other important metals having specific role in water quality such as $\mathrm{Cr}, \mathrm{Cd}$ and $\mathrm{Pb}$ were found to be well within permissible limits of WHO. 
Kumud C. Saikia and Susmita Gupta / American Journal of Environmental Science 8 (5) (2012) 523-527

Table 1. Variation of chemical, physical and biological parameters in water of ponds (P1-P4) handpumps (H1-H4) and river of Bidyanagar village (R1 and R2) (Values in parenthesis are $\pm \mathrm{SD}$ of three replicate samples)

\begin{tabular}{|c|c|c|c|c|c|c|c|c|c|c|}
\hline \multirow[b]{2}{*}{ Variables } & \multicolumn{4}{|l|}{ Pond } & \multicolumn{4}{|l|}{ Handpump } & \multicolumn{2}{|l|}{ River } \\
\hline & P1 & $\mathrm{P} 2$ & P3 & P4 & H1 & $\mathrm{H} 2$ & $\mathrm{H} 3$ & $\mathrm{H} 4$ & $\mathrm{R} 1$ & $\mathrm{R} 2$ \\
\hline WT $\left({ }^{\circ} \mathrm{C}\right)$ & $31.66(0.58)$ & $30.83(0.29)$ & $31.66(0.29)$ & $30.83(0.58)$ & $29.83(0.29)$ & $30.16(0.29)$ & $31.33(0.00)$ & $29.5(0.29)$ & $32.33(0.29)$ & $31.66(0.29)$ \\
\hline $\mathrm{DO} \mathrm{mgL}^{-1}$ & $6.77(0.34)$ & $7.54(0.29)$ & $5.81(0.58)$ & $7.44(0.44)$ & $7.83(0.58)$ & $8.81(0.16)$ & $7.04(0.62)$ & $6.53(0.51)$ & $7.42(0.42)$ & $7.22(0.27)$ \\
\hline Free $\mathrm{CO} 2\left(\mathrm{MgL}^{-1}\right)$ & $1.83(0.64)$ & $2.2(0.0)$ & $4.76(0.64)$ & $1.1(0.00)$ & $2.2(0.00)$ & $2.93(1.29)$ & $2.56(0.64)$ & $4.03(0.64)$ & $3.3(0.00)$ & $4.4(0.00)$ \\
\hline $\mathrm{TA}\left(\mathrm{mgL}^{-1}\right)$ & $53.33(2.89)$ & $83.33(2.89)$ & $45(5)$ & $75(5)$ & $81.67(2.89)$ & $78.57(7.15)$ & $61.66(2.89)$ & $68.33(2.89)$ & $90(5)$ & $83.33(2.89)$ \\
\hline $\mathrm{pH}$ & $6.88(0.02)$ & $5.98(0.02)$ & $7.18(0.01)$ & $7.24(0.03)$ & $7.95(0.05)$ & $6.88(0.02)$ & $7.52(0.02)$ & $8.12(0.01)$ & $6.84(0.02)$ & $7.82(0.01)$ \\
\hline $\mathrm{EC}\left(\mu \mathrm{S} \mathrm{cm}^{-1}\right)$ & $186.0(2.22)$ & $216.77(1.46)$ & $115.0(2.37)$ & $98.13(7.06)$ & $112.1(3.20)$ & $98.9(4.22)$ & $142.0(2.69)$ & $119.6(4.99)$ & $185.4(1.4)$ & $174.7(1.42)$ \\
\hline $\mathrm{Cd}\left(\mu \mathrm{g} \mathrm{L}^{-1}\right)$ & 4.0 & 3.5 & 1.7 & 2.5 & 1.8 & 4.3 & 1.5 & 0.6 & 4.1 & 3.2 \\
\hline $\operatorname{Cr}\left(\mu \mathrm{g} \mathrm{L}^{-1}\right)$ & 20.1 & 15.0 & 19.0 & 11.7 & 22.3 & 21.6 & 8.6 & 11.0 & 10.4 & 13.8 \\
\hline $\mathrm{Pb}\left(\mu \mathrm{g} \mathrm{L}^{-1}\right)$ & 10.8 & 13.4 & 10.4 & 10.2 & 22.6 & 15.0 & 20.1 & 12.1 & 6.6 & 11.8 \\
\hline E.coli (MPN $100 \mathrm{~mL}^{-1}$ ) & $26(3.57)$ & $33.3(2.08)$ & $40(7.49)$ & $40(6.94)$ & $3.3(0.57)$ & $20(3.43)$ & $3.3(0.57)$ & $10(7.28)$ & $50(9.25)$ & $50(11.08)$ \\
\hline $\begin{array}{l}\text { Other faecal Coli } \\
\text { form (MPN } 100 \mathrm{~mL}^{-1} \text { ) }\end{array}$ & $7543.3(5.13)$ & $7716.7(6.1)$ & $7946.7(8.6)$ & $5110(3.54)$ & $573.3(3.97)$ & $993.3(4.04)$ & $983.3(9.45)$ & $843.3(7.53)$ & $8856.7(8.0)$ & 8406.7 (4.04) \\
\hline
\end{tabular}

Typical Enter Pathogenic E. Coli (EPEC) strains are a leading cause of infantile diarrhea in developing countries (Ashbolt, 2004). In the present investigation, coli form bacteria count was found far beyond permissible limit in all the sources. According to permissible standards, if one or more than one E.coli per $100 \mathrm{~mL}$ of water is detected, the water is considered to be unsafe for drinking purposes. The number of E.coli and other fecal coli form in different drinking water sources of the village was recorded very high except in hand pumps. Highest number was recorded in river sources and lowest in hand pumps (Table 1). These results were corroborated with previous studies made in ponds of Catcher district, Assam and ponds, wells and natural reservoirs in and around Guwahati city, Assam (Sharma et al., 1995; Gupta et al., 2008). Microbiological properties of water of five Nigerian rivers also revealed similar results (Oluwande et al., 1980). It was observed that water samples of ponds situated near septic tanks, bathrooms and urinals showed higher values of coli forms. This showed lack of proper management practices in sanitary condition around the sources. Sharma et al. (1995) and Ayse et al. (2008) reported that surface water of river and pond frequently exposed to contaminated soil, sewage, domestic waste, untreated wastewater favored high bacterial load. Comparatively less bacterial count in hand pumps could be due to the filtering action of the earth which removes not only most of the bacteria but also much of their food material (Begum et al., 2004).

In a given situation with poor sanitation and poor-quality drinking water, the beneficial impact of improving only the sanitation will be larger than that of improving only the quality of drinking water (Esrey, 1996). In the study area, with arsenic contaminated ground water, surface water is the only option available to the inhabitants of arsenic effected villages. Hence for water borne diseases, people living in and around the surface water source. Need to be educated on hygiene practices and aware of their environmental impact on the drinking water. Public awareness programmes on simple and economical water treatment methods like filtration, boiling and SODIS (solar disinfection with UV plus heat in clear bottles for sunlight penetration) would prove beneficial. In developing countries, the availability of clean air, potable water, sanitation and safe food is often presumed to be low due to poverty. Individuals often lack the necessary information to make good decisions about environmental hazards in their day-to-day lives. Two most important factors operative in potable water quality conservation and management are education and economic condition of the population. A study on public perception of drinking water quality in Quebec region, Canada confirmed the importance of socio-economic characteristics of consumers on their perception of drinking water quality (Turgeon et al., 2004). Hence, a survey made for identifying the potential problems of surface water quality maintenance in the present study area revealed $60 \%$ of the population above 10th standard were aware of the arsenic problem because of their education. This knowledge is observed in their preference for water sources as $35 \%$ of people preferred ground water and $65 \%$ of people preferred surface water for drinking and treated water before use. The fate of 102 those $35 \%$ who have been using arsenic contaminated ground water is at risk to developing arsenocosis after prolonged exposure to the metal. Since the village has nearby surface water sources like river and ponds, water providers should take some ameliorative measures to control the microbial contamination of the aquatic systems in order to avoid the use of ground water. A study made on the socioeconomic impact of arsenic hazard on the poor people of rural society of Bangladesh showed that it caused social crisis and break up of social ties (Chowdhury et al., 2006). Risk of being affected by arsenic toxicity is increased and more prevalent among poor families. In the village, more than three fourth of the population are not in a position to have nutritious diet. Fortunately, there is no report of arsenocosis yet and ameliorative measures to lower arsenic concentrations in ground water can still be effective to protect human health in this area. 


\section{CONCLUSION}

This study finds that a phased water quality monitoring programme should be undertaken for improvements in water quality. Effluents should be treated to acceptable levels and standards before discharging them into natural streams. Allocation of funds under the water resources sector should be reprioritized to ensure that the needs for development as well as operation and maintenance of the facilities are met. Structures and systems created through massive investments should be properly maintained in good health.

\section{ACKNOWLEDGEMENT}

The researchers are thankful to the Head, Dept. of Ecology and Environmental Science, Assam University, Silchar, Assam, India for providing laboratory facilities. The first author is thankful to University Grants Commission, New Delhi, India for financial support.

\section{REFERENCES}

Ashbolt, N.J., 2004. Microbial contamination of drinking water and disease outcomes in developing regions. Toxicology, 198: 229-238. DOI: 10.1016/j.tox.2004.01.030

Ayse, E., F.O. Topac., N. Ozengin, A. Teksoy and S. Kurtoglu et al., 2008. Evaluation of physical, chemical and microbiological properties of lake Uluabat, Turkey. J. Environ. Biol., 29: 205-210. PMID: 18831376

Begum, J., K. Ahmed, K.N. Bora and A. Hussain, 2004. Coliform bacteria in different sources of drinking water during different seasons. Poll. Res., 23: 607-609.

Bhuiyan, J.R. and S. Gupta, 2007. A Comparative hydrobiological study of a few ponds of barak valley, assam and their role as sustainable water resources. J. Environ. Biol., 28: 799-802.

Chowdhury, M.A.I., M.T. Uddin, M.F. Ahmed, M.A. Ali and S.M.A. Rasul et al., 2006. Collapse of socioeconomic base of bangladesh by arsenic contamination in ground water. J. Biol. Sci., 9: 1617-1627.

Dwivedi, B.K. and G.C. Pandey, 2002. Physico-chemical factors and algal diversity of two ponds (girija kund and maqubara pond), Faizabad, India. Poll Res., 21: 361-370.

Eaton, A.D. and M.A.H. Franson, 2005. Standard Methods for the Examination of Water and Wastewater. 1st Edn., American Public Health Association, Washington, DC., ISBN-10: 0875530478, pp: 1200.

Esrey, S.A., 1996. Water, waste and wellbeing. A multicountry study. Am. J. Epidemiol., 3: 608-23.

Esrey, S.A., R.G. Feacham and J.M. Hughes, 1985. Interventions for the control of diarrhoeal diseases among young children. Improving water supplies and excreta disposal facilities. Bull. World Health Org., 63: 757-772.
Gupta, A., 2004. drinking water quality in barak valley. Proceedings of the 2nd APHW Conference. Asia Pacific Association of Hydrology and Water Resources, Japan. pp: 621-627.

Gupta, S., K. Buragohain and J.R. Bhuiyan, 2008. Importance of ponds in integrated water resource management in barak valley. Poll. Res., 27: 587-590.

Gupta, S.K. and R.D. Deshpande, 2004. Water for India in 2050. First Order assessment of available options. Curr. Sci., 86: 1216-1224.

Mahapatra, M.K. and H.S. Mishra, 2005. Ground water pollution in subarnapur and nuapada districts of Orissa. India. Poll. Res., 24: 863-865.

Martin, P., M.A. Haniffa and M. Arunachalam, 2000. Abundance and diversity of macroinvertibrates and fish in the tambaraparani river, South India. Hydrobiol., 430: 59-75. DOI: 10.1023/A:1004021130297

Murdock, S.H., F.L Leistritz and R.R. Hamm, 1986. The State of socioeconomic impact analysis in the United States of America. Limitations and opportunities for alternative futures. J. Environ. Manage., 23: 99-117.

Naik, A.A. and A. Wanganeo, 2008. Seasonal variation of heavy metals in surface water samples of upper basin of bhoj wetlands, Bhopal. Poll Res., 27: 649-653.

NWP, 2002. Ministry of water resources. Govt. of India, New Delhi.

Oluwande, P.A., M.K. Sridhar, A.O. Bammeke and A.O. Okubadejo, 1980. Pollution levels in some nigerian rivers. Water Res., 17: 957-963. DOI: 10.1016/0043-1354(83)90035-0

Parikh, K.S., J. Parikh and T.L. Raghu Ram, 1999. Air and Water Quality Management: New Initiatives Needed. In: India Development Report, Parikh, K.S., (Ed.)., Oxford University Press, New Delhi.

Sharma, C., D.K. Deka and K.G. Bhattacharyya, 1995. Bacteriological quality of a few entrapped water sources in and around guwahati. J. Environ. Protection, 15: 850-852.

Singh, A.K., 2004. Arsenic Contamination in Ground Water of North East India. Proceedings of 11th National Symposium on Hydrology with Focal Theme on Water Quality, (HFTWQ' 04), National Institute of Hydrology, Roorkee, pp: 255-262.

Smith, A.H., E.O. Lingas and M. Rahman, 2000. Contamination of drinking-water by arsenic in Bangladesh: A public health emergency. Bull. World Health Organ., 78: 1093-1093.

Turgeon, S., J. M Rodriguez, M. Theriault and P. Levallois, 2004. Perception of drinking water in the quebec city region (Canada). The influence of water quality and consumer location in the distribution system. J. Environ. Manage., 70: 363-373.

WHO, 2004. Guideline for Drinking Water Quality. 3rd Edn., World Health Organization, Geneva, pp: 104.

WHO, 2002. The world health report 2002-Reducing Risks. Promoting Healthy Life World Health Organization, Geneva. 